\title{
Investigation of Serum and Leukocyte Ascorbic Acid, Plasma and Intra-Erythrocyte Cholinesterase Levels in Obese Persons
}

\section{Obez Kişilerde Serum ve Lökosit Askorbik Asit, Plazma ve Intra-Eritrosit Kolinesteraz Seviyelerinin Incelenmesi}

\author{
Elif Menekşe' \\ 'Amasya University Sabuncuoğlu Şerefeddin Training and Research Hospital. Division of Clinical Chemistry' Amasya' Turkey
}

\begin{abstract}
Introduction: Obesity is a complicated disease, including excessive amounts of body fat. Obesity is not just an aesthetic problem. It is also a medical issue that increases your risk of other diseases and health conditions, like heart disease, diabetes, and certain cancers. Ascorbic acid (AA) produced analog enhancing effects in superoxide generation, DNA strand cutting, and cytotoxicity. In leukocytes, toxicity due to mitochondrial permeability was seen in cells exposed to AA/peroxynitrite, and these responses were determined to occur independently of Ca2+. Plasma cholinesterase and erythrocyte acetylcholinesterase activities have a long history of use in monitoring workers at risk for organophosphorus pesticide (OPP) exposure. Due to the wide variation between individuals, it is necessary to establish unexposed, essential enzyme activities for correct interpretation.

Material and Method: Forty-four females and 32 males with a mean age of $40 \pm 11.4$ years were included in our study. In our study, those with a BMI of 18-24 were considered as control or non-obese (group 1), those between 25 and 30 as obese (group 2), and those between 31 and 42 as extremely obese (group 3). With a moderate standard deviation of 70 and $20 \%$ erosion rate, 76 subjects were determined for $93 \%$ power at the $5 \%$ level of significance. Baseline comparisons among treatment sequences were analyzed using a chi-square test for categorical variables and an unpaired t-test for continuous variables. Mean and standard deviation values were assessed using the SPSS package program, and a statistically significant difference was determined at p-level below 0.05 value.

Results: As a result; Although the increase in PCE levels and the decrease in $E C E, P T A$, and PA levels were significantly different. The difference between group 2 and group 3 revealed the importance of these differences between obese and non-obese patients.

Discussion: It has been determined that as obesity increases, the risk of vitamin deficiency also increases. The superior bioavailability of EC in leukocytes may be beneficial to overall immune function since intracellular vitamin C levels are vital to the fundamental process of leukocytes. More studies are needed to understand better how EC is associated with disease prevention and treatment.
\end{abstract}

Keywords: Ascorbic acid, erythrocyte cholinesterase, obesity
Öz

Amaç: Obezite, aşırı miktarda vücut yağı içeren karmaşık bir hastalıktır. Obezite sadece estetik bir problem değildir. Aynı zamanda kalp hastalığı, diyabet ve bazı kanserler gibi diğer hastalıklar ve sağlık koşulları riskinizi artıran tıbbi bir sorundur. Askorbik asit (AA), süperoksit üretimi, DNA ipliği kesimi ve sitotoksisitede analog artırıcı etkiler üretir. Lökositlerde, AA/peroksinitrite maruz kalan hücrelerde mitokondriyal geçirgenliğe bağlı toksisite görülmüş ve bu yanıtların Ca2+ 'dan bağımsız olarak oluştuğu belirlenmiştir. Plazma kolinesteraz ve eritrosit asetilkolinesteraz aktiviteleri, organofosfor pestisit (OPP) maruziyeti riski alıındaki çalışanları izlemede uzun bir kullanım geçmişine sahiptir. Bireyler arasındaki geniş çeşitlilik nedeniyle, doğru yorumlama için maruz kalmamış, gerekli enzim aktivitelerinin oluşturulması gerekmektedir.

Gereç ve Yöntem: Çalışmamıza yaş ortalaması $40 \pm 11,4$ olan 44 kadın ve 32 erkek dahil edildi. Çalışmamızda VKI'si 18-24 arasında olanlar kontrol veya obez olmayanlar (grup 1), 25-30 arası olanlar obez (grup 2) ve 31-42 arası aşırı obez (grup 3) olarak kabul edildi. \% 70 ve\% $20^{\prime}$ lik orta standart sapma ile,\% 5 anlamlılık düzeyinde\% 93 güç için 76 denek belirlendi. Tedavi sekansları arasındaki temel karşılaşıımalar, kategorik değişkenler için bir ki-kare testi ve sürekli değişkenler için eşleşmemiş bir t testi kullanılarak analiz edildi. Ortalama ve standart sapma değerleri SPSS paket programı kullanılarak değerlendirildi ve 0,05 değerinin altında p düzeyi ile istatistiksel olarak anlamlı fark kabul edildi. Sonuç: Sonuç olarak; EBE düzeylerindeki artış ve EÇE, PTA ve PA 'da azalma olmasına rağmen seviyeleri önemli ölçüde farklıydı. Grup 2 ile grup 3 arasındaki fark, obez ve obez olmayan hastalar arasındaki bu farklııkların önemini ortaya koydu.

Tartışma: Obezite arttıkça vitamin eksikliği riskinin de arttığı tespit edilmiştir. EC'nin lökositlerdeki üstün biyoyararlanımı, hücre içi C vitamini seviyeleri lökositlerin temel süreci için hayati önem taşıdığından, genel bağışıklık fonksiyonu için faydalı olabilir. EC'nin hastalık önleme ve tedavi ile nasıl ilişkili olduğunu daha iyi anlamak için daha fazla çalışmaya ihtiyaç vardır.

Anahtar Kelimeler: Askorbik asit, eritrosit kolinesteraz, obezite

Corresponding (IIletişim): Elif Menekşe, Amasya University Sabuncuoğlu Şerefeddin Training and Research Hospital, Division of Clinical Chemistry, Amasya, Turkey

E-mail (E-posta): elifzehra2008@hotmail.com

Received (Geliş Tarihi): 16.12.2020 Accepted (Kabul Tarihi): 12.03.2021 


\section{INTRODUCTION}

Obesity is a complicated disease, including excessive amounts of body fat. Obesity is not just an aesthetic problem. It is also a medical issue that increases your risk of other diseases and health conditions, like heart disease, diabetes, and certain cancers. There are several causes of why some people have trouble avoiding obesity. Constantly obesity outcomes from genetic factors with the environment, personal diet, and exercise options. The good news is that even a humble weight sacrifice can develop or prohibit health problems related to obesity. Food intake changes, increased physical activity, and behavioral changes can help you lose heaviness. Recipe drug usage and weight loss procedures are additional options for obesity treatment. ${ }^{[1]}$ Obesity, which tends to increase day by day, is a significant social and clinical problem. The mortality risk is higher than non-obese people. In this study, it was aimed to investigate the relationship between the degree of obesity and vitamin $C$, the relationship between the degree of obesity and cholinesterase, whether there is a relationship between vitamin $C$ and cholinesterase, as well as to determine the degree of vitamin C deficiency in obese patients.

Ascorbic acid (AA) produced analog enhancing effects in superoxide generation, DNA strand cutting, and cytotoxicity. However, while AA failed to improve the intra-leukocyte mitochondrial concentration of $\mathrm{Ca}^{2+}$ and the effects observed in cells supplemented with peroxynitrite, it was not affected by inhibiting $\mathrm{Ca}^{2+}$ mobilization or mitochondrial accumulation of the cation. Simultaneously, it was also detected in human monocytes and detected in macrophages not expressing the ryanodine receptor. In leukocytes, toxicity due to mitochondrial permeability was seen in cells exposed to AA/ peroxynitrite, and these responses were determined to occur independently of $\mathrm{Ca}^{2+}$ according to the above criteria. Thus, the stimulatory effects of AA are similar to those mediated by complex III inhibitors. However, the vitamin failed to inhibit complex III directly and increased its sensitivity to peroxynitrite's inhibitory effects. ${ }^{[2]}$

Plasma cholinesterase and erythrocyte acetylcholinesterase activities have a long history of use, both in monitoring workers at risk for organophosphorus pesticide (OPP) exposure and investigating accidental exposures to OPPs. Due to the wide variation between individuals, it is necessary to establish unexposed, essential enzyme activities for correct interpretation. OPP exposure inhibits plasma cholinesterase activity more than erythrocyte acetylcholinesterase activity. ${ }^{[3]}$

Obesity is one of the crucial health threats worldwide. Therefore, antioxidant-based treatments could be considered as exciting approaches to prevent obesity from fat aggregation complications. In this format, it has been shown that vitamin C intake (ascorbic acid) is negatively associated with the onset of various conditions such as hypertension, gall bladder disease, stroke, cancer, and atherosclerosis as the beginning of obesity in humans and animals. Among the possible beneficial effects of ascorbic acid on obesity-related mechanisms, it has been suggested that this vitamin may: (a) modulate adipocyte lipolysis; (b) regulation of glucocorticoid release from the adrenal glands; (c) inhibits glucose metabolism and leptin secretion on isolated adipocytes; (d) leads to an improvement in hyperglycemia and a decrease in glycosylation in obese-diabetic models; and (e) reducing the inflammatory response. Probably all these properties could be related to the extraordinary antioxidant properties of this vitamin. Butyrylcholinesterase can be useful in lipid metabolism by direct interaction of cholesterol or cholesterol esters. Studies are conducted to reveal the relationship between cholinesterase activity and triacylglycerol levels, obesity, type 2 diabetes mellitus, and fatty liver. ${ }^{[4]}$

Additionally, it is thought that a high-fat diet in mice lacking the butyrylcholinesterase gene causes obesity. HMG-CoA reductase inhibitors and statins are considered to have inhibitory properties on cholinesterases. It is known that statins and similar lipid-lowering agents reduce cholesterol levels and act as a protective agent against Alzheimer's disease. The subject of new research is that they can be protective-preventive agents for conditions such as lipid metabolism, cardiovascular diseases, and stroke. ${ }^{[5]}$

This study tried to evaluate the relationship between serum and intra-leukocyte ascorbic acid and plasma and intraerythrocyte cholinesterase levels in controls and obese individuals.

\section{MATERIAL AND METHOD}

Forty-four females and 32 males with a mean age of $40 \pm 11.4$ years were included in our study. In our study, those with a BMI of 18-24 were considered as control or non-obese (group 1), those between 25 and 30 as obese (group 2), and those between 31 and 42 as extremely obese (group 3). The study consists of 24-h test periods, each preceded by a 7-day washout period. ${ }^{[6]}$ During the Screening Visit, subjects' medical history and other therapies were reviewed, and qualification was determined based on the inclusion and exclusion criteria. Blood samples and analyzed for the pharmacokinetics of plasma and leucocyte vitamin C. Blood was collected in a 6 $\mathrm{mL}$ sodium heparin tube (BD Vacutainer, Mississauga, Ontario) inverted several times to ensure a complete mixture of blood and anticoagulant. The tube was centrifuged at $4^{\circ} \mathrm{C}$ for 10 min at $3000 \mathrm{rpm}$ to separate the plasma and buffy coat layers. Absorbance measurements were obtained on a Perkin-Elmer (Waltham, Massachusetts, USA) (Lambda-15) UV/visible dualbeam spectrophotometer and paired $10 \mathrm{~mm}$ silica cuvettes. The necessary reagents and sample preparation processes for the study were carried out manually in the laboratory. Cholinesterase levels were assessed using an improved version of Garry and Routh's colorimetric assay for serum pseudocholinesterase [Clin. Chem. 11, 91 (1965)] and a variation of this method for measuring cholinesterase in cells. Ascorbic acid concentrations were calculated by subtracting the measured ascorbic acid concentration from that of total 
ascorbic acid analyzed after reducing the dehydroascorbic acid present; a method referred to as the subtraction method. Other biochemical parameter data were obtained from medical records. Comparative analysis was performed by studying and calculating the parameters stated below:

- Lipid and lipoprotein parameters as triglyceride (Trig.), total cholesterol (T.Kol), HDL-cholesterol (HDL), LDLcholesterol (LDL),

- Free blood sugar (FBG),

- Plasma cholinesterase (PCE), intra-erythrocyte cholinesterase ( ECE),

- Total plasma ascorbate (PTA), plasma ascorbate (PA), plasma hydro-ascorbate (PDA), total leukocyte ascorbate (LTA), leukocyte ascorbate (LA), leukocyte dehydroascorbate (LDA),

- PDA/PA, PDA/PTA, PA/PTA, LDA/LA, LDA/LTA, LA/LTA ratios,

It was aimed to determine

a) the relationship between the degree of obesity and vitamin $C$,

b) the relationship between the degree of obesity and cholinesterase, and

c) the relationship between vitamin $\mathrm{C}$ and cholinesterase and the determination of vitamin $C$ deficiency levels in obese patients.

With a moderate standard deviation of 70 and $20 \%$ erosion rate, 76 subjects were determined for $93 \%$ power at the $5 \%$ level of significance. Baseline comparisons among treatment sequences were analyzed using a chi-square test for categorical variables and an unpaired t-test for continuous variables. Mean and standard deviation values were assessed using the SPSS package program, and a statistically significant difference was determined at $\mathrm{p}$-level below 0.05 value.

\section{RESULTS}

In the controls (group 1) the results were; PTA $1.26 \pm 0.69 \mathrm{mg} / \mathrm{dL}$, PA $1.13 \pm 0.66 \mathrm{mg} / \mathrm{dL}$, PDA $0.11 \pm 0.09 \mathrm{mg} / \mathrm{dL}$, LTA $36.97 \pm 14.98$ ug/108 leuc, LA $22.45 \pm 7.68 \mathrm{ug} / 108$ leuc, LDA $14.52 \pm 7.66$ ug/108 leuc, PCE 5685 \pm 1014 U/L, ECE $28.24 \pm 8.10 \mathrm{gr} / \mathrm{Hb}$, FBG $99.7 \pm 14 \mathrm{mg} / \mathrm{dl}$, Trig. $79.5 \pm 45 \mathrm{mg} / \mathrm{dl}$, Col. $165.65 \pm 35 \mathrm{mg} / \mathrm{dl}$, HDL $47.86 \pm 7.41 \mathrm{mg} / \mathrm{dL}, \mathrm{LDL} 116.54 \pm 25 \mathrm{mg} / \mathrm{dL}$. In the obeses (group 2) the results were; PTA $0.86 \pm 0.40 \mathrm{mg} / \mathrm{dL}$, PA $0.78 \pm 0.43$ $\mathrm{mg} / \mathrm{dL}$, PDA $0.12 \pm 0.07 \mathrm{mg} / \mathrm{dL}$, LTA $34.29 \pm 13.4 \mathrm{pg} / 108$ leuc, LA $21.95 \pm 6.39 \mathrm{ug} / 108$ leuc, LDA $12.34 \pm 7.41 \mathrm{ug} / 108$ leuc, PCE $6884 \pm 1535 \mathrm{U} / \mathrm{L}$, ECE $22.64 \pm 7 \mathrm{U} / \mathrm{gr} \mathrm{Hb}$, FBG $110 \pm 9.3 \mathrm{mg} / \mathrm{dL}$, Trig. $121.8 \pm 49 \mathrm{mg} / \mathrm{dL}$, T. Kol. $201.1 \pm 39 \mathrm{mg} / \mathrm{dL}, \mathrm{HDL} 47.27 \pm 9$ $\mathrm{mg} / \mathrm{dL}$, LDL $139.5 \pm 51.7 \mathrm{mg} / \mathrm{dL}$. In the malignant obeses (group 3) the results were; PTA $0.70 \pm 0.29 \mathrm{mg} / \mathrm{dL}$, PA $0.60 \pm 0.26$ $\mathrm{mg} / \mathrm{dL}$, PDA $0.11 \pm 0.09 \mathrm{mg} / \mathrm{dL}$, LTA $35.41 \pm 12.4 \mathrm{ug} / 108$ leuc, LA 22.49 \pm 5.83 ug/108 leuc, LDA $12.92 \pm 6.95$ ug/108 leuc PCE $7470 \pm 1240 \mathrm{U} / \mathrm{L}$, ECE $24.59 \pm 4.49 \mathrm{U} / \mathrm{grHb}$, FBG $117.6 \pm 17.6 \mathrm{mg} /$ dL, Trig. $145.9 \pm 64.2 \mathrm{mg} / \mathrm{dL}$, T.Kol $221.7 \pm 51.7 \mathrm{mg} / \mathrm{dL}$, HDL $47.6 \pm 9.7 \mathrm{mg} / \mathrm{dL}$, LDL $149.4 \pm 50.6 \mathrm{mg} / \mathrm{dL}$. FBG, Trig., T. Kol. and
LDL levels the parameters have a positive correlation with $\mathrm{BMI}$; $r: 0.41, p<0.001 ; r: 0.44, p<0.001 ; r: 0.54, p<0.001$, respectively. PCE levels gradually increased according to $\mathrm{BMI}$ and this increase was higher between the first two groups $(p<0.001)$ and between group 2 and $3(p<0.001)$. ECE levels gradually decreased compared to BMI and this decrease was statistically significant especially between group 1 and group $2(p<0.05)$ and between group 2 and group $3(p<0.05)$. PTA and PA levels tend to decrease compared to $\mathrm{BMI}$, and this decrease is in between group 1 and group 2 shows $p<0.05$ value and in between group 1 and group 3 the $p$ value was $<0.001$. No significant difference was found in PDA, LTA, LA and LDA values compared to BMI. Group values of mean and SD are given in Table 1.

\begin{tabular}{lccc}
\multicolumn{4}{l}{ Table 1. Mean and SD values of biochemical parameters among groups } \\
Parameters & Control & Obese & Morbid Obese \\
PTA (mg/dL) & $1.26 \pm 0.69$ & $0.86 \pm 0.40$ & $0.70 \pm 0.29$ \\
PA (mg/dL) & $1.13 \pm 0.66$ & $0.78 \pm 0.43$ & $0.60 \pm 0.26$ \\
PDA (mg/dL) & $0.11 \pm 0.09$ & $0.12 \pm 0.07$ & $0.11 \pm 0.09$ \\
LTA (ug/108 leuc) & $36.97 \pm 14.98$ & $34.29 \pm 13.4$ & $35.41 \pm 12.4$ \\
LA (ug/108 leuc) & $22.45 \pm 7.68$ & $21.95 \pm 6.39$ & $22.49 \pm 5.83$ \\
LDA (ug/108 leuc) & $14.52 \pm 7.66$ & $12.34 \pm 7.41$ & $12.92 \pm 6.95$ \\
PCE (U/L) & $5685 \pm 1014$ & $6884 \pm 1535$ & $7470 \pm 1240$ \\
ECE (gr/Hb) & $28.24 \pm 8.10$ & $22.64 \pm 7$ & $24.59 \pm 4.49$ \\
FBG (mg/dL) & $99.7 \pm 14$ & $110 \pm 9.3$ & $117.6 \pm 17.6$ \\
Trig (mg/dL) & $79.5 \pm 45$ & $121.8 \pm 49$ & $145.9 \pm 64.2$ \\
T. Col (mg/dL) & $165.65 \pm 35$ & $201.1 \pm 39$ & $221.7 \pm 51.7$ \\
HDL (mg/dL) & $47.86 \pm 7.41$ & $47.27 \pm 9$ & $47.6 \pm 9.7$ \\
LDL (mg/dL) & $116.54 \pm 25$ & $139.5 \pm 51.7$ & $149.4 \pm 50.6$ \\
\hline
\end{tabular}

\section{DISCUSSION}

Under normal conditions, vitamin $C$ exists as both ascorbate (reduced form, AA) and dehydroascorbate (DHA, oxidized form). It has been reported that leukocytes predominantly ingest vitamin $\mathrm{C}$ in the form of DHA in a passive, gradientdependent manner. ${ }^{[7]}$ This uptake is affected by the initial oxidation of vitamin $\mathrm{C}$ to $\mathrm{DHA}$ and its reduction to $\mathrm{AA}$ once it enters the cell. This lets leukocytes store vitamin C at higher concentrations than plasma, which is essential for proper cellular function. ${ }^{[8]}$ The vitamin $C$ metabolites generated after oxidation to DHA are thought to maintain the extracellular oxidation and metabolism of DHA and/or empower the passive, facilitated, or active transport signaling mechanisms required for intracellular Access. ${ }^{[9]}$ The high retention of vitamin $C$ in leukocytes helps provide maximum cellular levels of vitamin $C$ for normalized biochemical activity, including immune function. In a study with two non-ascorbate synthesizing rats, EC-fed animals showed higher vitamin $C$ activity, and body weight gain than the group provided AA. ${ }^{[10]}$ In humans, leukocytes' fundamental processes, specifically neutrophil phagocytic capacity, can be lowered when leukocytes have less vitamin C. Besides, repletion with vitamin $\mathrm{C}$ can help restore these crucial 
functions. ${ }^{[11]}$ To the best of our knowledge, one published clinical trial has demonstrated the disease treatment roles of vitamin C-the study determined that compared to placebo, EC (1000 mg of vitamin C per day) can significantly lessen colds and shorten the duration of severe symptoms in winter over two months. ${ }^{[12]}$ Vitamin $C$ supports the immune system, alleviates allergic reactions, and protects against fighting infections thanks to its antioxidant effect. However, vitamin C's importance and beneficial impact in clinical conditions such as cancer, atherosclerosis, diabetes, neurodegenerative disease, and metal toxicity remains unclear. ${ }^{[13]}$ However, vitamin $C$ has various roles as an antioxidant that protects immune cells against damage by intracellular reactive oxygen radicals (ROR) during the inflammatory response, acts as an enzymatic cofactor, ensures tissue integrity, and plays a critical role in the formation of skin, epithelial and endothelial barriers. ${ }^{[14]}$ Knowing the levels of intracellular fluid and intracellular vitamin C can provide an idea about the effectiveness of our biological defense mechanisms, as provided by the results of our study. Further studies are needed to analyze how the level of vitamin C in leukocytes affects neutrophil function and is associated with disease prevention and treatment. The leukocyte vitamin $\mathrm{C}$ concentrations reported in our study can serve as future reference values.

OPPs are hazardous components and are insecticides that cause diseases that can result in death. Overexposure can lead to clinical situations requiring immediate intervention. Their mechanism of action is through inhibition of the cholinesterase enzyme in the nervous system. Symptoms and signs depend on the balance between nicotinic and muscarinic receptors. Treatment consists of general supportive therapy, decontamination, inhibition of absorption, and antidote administration. Depending on the dose resulting from toxicity, nonspecific influenzalike situations may be seen, specific findings may develop, and the clinical picture can be defined as mild, moderate, and severe toxicity. ${ }^{[15]}$ The researchers found no significant relationship between the severity of OPP poisoning and ECG findings in terms of mortality. They indicated a statistically significant association between low serum cholinesterase level and mortality in severe intoxication. ${ }^{[16]}$ Examination findings may not be clearly defined according to the clinically experienced physician's knowledge. It may be delayed in the differential diagnosis, and it may be challenging to differentiate the clinical picture with precise limits. For this reason, the ability to make measurements, as we did in our study, can be vital for certain patients.

\section{CONCLUSION}

As a result; Although the increase in PCE levels and the decrease in ECE, PTA, and PA levels were significantly different. The difference between group 2 and group 3 revealed the importance of these differences for obese and non-obese patients. It has been determined that as obesity increases, the risk of vitamin deficiency also increases. This study will be useful in providing an idea to emergency physicians about the ECG findings that can be seen in OPP poisoning and its effects on mortality and contributing to their clinical experience. However, more detailed studies are needed on this subject.

\section{ETHICAL DECLARATIONS}

Ethics Committee Approval: This study was prepared by Elif Menekşe's 1995 thesis. Since the ethics committee approval was not required for the study under the time conditions, no ethics committee application was made.

Informed Consent: All patients signed the free and informed consent form.

Referee Evaluation Process: Externally peer-reviewed.

Conflict of Interest Statement: The authors have no conflicts of interest to declare.

Financial Disclosure: The authors declared that this study has received no financial support.

Author Contributions: Author declare that they have all participated in the design, execution, and analysis of the paper, and that they have approved the final version.

\section{REFERENCES}

1. World Health Organisation, Health Topics, Obesity. Last updated at 3.12.2020 https://www.who.int/health-topics/obesity\#tab=tab_1

2. Barlak Keti D, Muhtaroğlu S,Saraçoğlu H. Askorbik Asidi Ölçen veya Dirençli olan Stripler: Hangisi Tercih Edilmeli? Türk Klinik Biyokimya Derg 2017;15(3):107-13.

3. Venkataraman BV, lyer GY, Narayanan R, Joseph T. Erythrocyte and plasma cholinesterase activity in normal pregnancy. Indian J Physiol Pharmacol 1990;34(1):26-8.

4. Gökçen M, Gökbel H, Kaptanoğlu B, et al. Değişik Vücut Ağırlıklarına Sahip Kişilerde Plazma ve Eritrosit İçi Kolinesteraz Aktiviteleri ve Çeşitli Plazma Parametre Değerleri [Plasma and erythrocyte cholinesterase activities and values of some plasma parameters in subjects with different body weight]. Turgut Ozal Tip Merkezi Derg 1994;1:126-31.

5. Mutlu F , Şimşek Z , Cici M . GAP Bölgesi'nde Pestisit Satış Yerlerinde Çalışanlarda Kolinesteraz İnhibitörleri ve Karaciğer Enzim Düzeylerinin İncelenmesi. Harran Univ Vet Fak Derg 2017;6(1):57-62.

6. Moyad MA, Combs MA, Vrablic AS, Velasquez J, Turner B, Bernal S Vitamin $C$ metabolites, independent of smoking status, significantly enhance leukocyte, but not plasma ascorbate concentrations. Adv Ther. 2008;25(10):995-1009.

7. LiY, Schellhorn HE. New developments and novel therapeutic perspectives for vitamin C. J Nutr 2007;137(10):2171-84.

8. Bergsten P, Amitai G, Kehrl J, Dhariwal KR, Klein HG, Levine M. Millimolar concentrations of ascorbic acid in purified human mononuclear leukocytes. Depletion and reaccumulation. J Biol Chem. 1990; 265(5):2584-7.

9. Moyad MA, Combs MA, Vrablic AS, Velasquez J, Turner B, Bernal S. Vitamin $C$ metabolites, independent of smoking status, significantly enhance leukocyte, but not plasma ascorbate concentrations. Adv Ther. 2008; 25(10):995-1009.

10. Verlander AJ, Fay MJ, Bannon AW. Comparison of the anti-scorbutic activity of L-ascorbic acid and Ester $C$ in the non-ascorbate synthesizing Osteogenic Disorder Shionogi (ODS) rat. Life Sci. 1991;48(23):2275-81. 
11. Jayachandran M, Rani P, Arivazhagan P, Panneerselvam C. Neutrophil phagocytic function and humoral immune response concerning ascorbate supplementation in aging humans. J Anti Aging Med. 2000;3(1):37-42.

12. Preventing the common cold with a vitamin $C$ supplement: a doubleblind, placebo-controlled survey. Van Straten M, Josling P Adv Ther. 2002; 19(3):151-9.

13. Chambial S, Dwivedi S, Shukla KK, John PJ, Sharma P. Vitamin C in disease prevention and cure: an overview. Indian J Clin Biochem 2013;28(4):31428.

14. Holmannová $D$, Koláčková $M$, Krejsek J. Fyziologická úloha vitaminu C ve vztahu ke složkám imunitního systému [Vitamin $\mathrm{C}$ and its physiological role with respect to the components of the immune system]. Vnitr Lek. 2012;58(10):743-9.

15. Robey WC, Meggs WJ. Insecticides, Herbicides, and Rodenticides. In: Tintinalli JE, Kelen GD, Stapczynski JS, eds. Emergency Medicine: a Comprehensive Study Guide. 6th Edn. McGraw-Hill Co, New York, 2004; pp. 1134-43.

16. Atlı $M$, Sebe A, Ay $M$, et al. "Akut Organofosfat Zehirlenmelerinde Elektrokardiyografik Değişiklikler Ile Kolinesteraz Düzeylerinin Mortaliteye Etkileri". Cukurova Med J 2013;38:181-8. 